\title{
Transposition
}

Musique et Sciences Sociales

\section{Boy Bands, Drag Kings, and the Performance of (Queer) Masculinities}

Jennifer $\mathrm{J}$ Moos

\section{(2) OpenEdition}

\section{Journals}

\section{Electronic version}

URL: http://journals.openedition.org/transposition/325

DOI: 10.4000/transposition.325

ISSN: 2110-6134

\section{Publisher}

CRAL - Centre de recherche sur les arts et le langage

\section{Electronic reference}

Jennifer J* Moos, «Boy Bands, Drag Kings, and the Performance of (Queer) Masculinities », Transposition [Online], 3 | 2013, Online since 01 March 2013, connection on 19 April 2019. URL : http:// journals.openedition.org/transposition/325 ; DOI : 10.4000/transposition.325

This text was automatically generated on 19 April 2019

\section{(c) (i) (?)}

La revue Transposition est mise à disposition selon les termes de la Licence Creative Commons Attribution - Partage dans les Mêmes Conditions 4.0 International. 


\title{
Boy Bands, Drag Kings, and the Performance of (Queer) Masculinities
}

\author{
Jennifer $\mathrm{J}^{*}$ Moos
}

\section{Setting the Stage}

1 Boy band culture had its heyday during the mid- and late 1990s when innumerable boy bands were casted in order to successfully conquer the music market. At that time, teen magazines all over (Western) Europe ${ }^{1}$ were populated by pictures of handsome-looking young men coming right from their fans' neighborhoods. These "boys" most often embodied the perfect mother-in-law's delights.

2 At first sight, the boy band phenomenon seems to have evolved around a rather heteronormatively structured pattern of singing and dancing boys on stage and screaming, sometimes even fainting, girls in front of the stage. "Boy Bands, Drag Kings, and the Performance of (Queer) Masculinities" questions this rigidly binary-gendered assumption by exploring constructions of masculinity in 1990s boy band culture. My "queer reading" of the boy band phenomenon will be performed on three different levels: In reference to the Backstreet Boys and Take That, I will argue that the "manufacturing processes" involved in the fabrication of a boy band as well as the fact that boy bands are promoted primarily via audio-visual material such as the band's music videos evolves into a specific "boy band masculinity". This soft, "innocent" masculinity or even "girlishness"2 heavily relies on markers of gay culture, as will be seen in my discussion of the Backstreet Boys' video "Quit Playing Games (With My Heart)" (1996). As a next step, I will connect my analysis to re-interpretations and re-significations of boy band masculinity by punk rockers, all-boy high school groups, and two different drag (king) troupes. ${ }^{3}$ By referring to and citing from boy band masculinity, these troupes use strategies of exaggeration and parody as a socio-cultural criticism against heteronormatively structured gendered biases. In a final step, I want to draw attention to boy bands' performances in the new 
millennium: In reference to Take That's video "Happy Now" (2011), I will show that those boy bands from the 1990s that are still in the business have started to adopt parodic styles themselves in order to distance themselves self-consciously from "traditional", heteronormative masculinities and additionally, and maybe even more importantly, from their (former) boy band image.

\section{Stage-Lighting on, or. What makes a Boy Band a Boy Band?}

3 Although one might argue that bands such as the Beatles, The Monkees, or even the Jackson 5 could be referred to as boy bands, the first boy band in the sense of the term as it has been used since the 1990s was New Kids on the Block (NKOTB), a band from Boston, Massachusetts, that was formed in 1984 and had achieved international success by 1988 . What followed was a wave of success for boy bands, especially in Western Europe and Asia. In the 1990s, innumerable boy bands were casted during elaborate audition processes in order to conquer the inter- and transnational music market. The first European boy band, Take That (1990), was put together by their manager Nigel MartinSmith in Manchester, Great Britain. They were followed by East 17 (1991) and Worlds Apart (1992), the Dutch bandCaught in the Act (1992), the Irish bands Boyzone (1993) and Westlife (1998), as well as by German boy bands such as, for example, Bed \& Breakfast (1995). In the U.S., Lou Pearlman was the most successful manager in the boy band business. In 1993, he formed theBackstreet Boys and two years later *NSYNC with Justin Timberlake as one of the band's five members. Today, the Backstreet Boys are still being advertised as the bestselling boy band of all times. As portrayed from left to right on the cover of the band's first album "Backstreet Boys" (1996), the Backstreet Boys from Orlando, Florida, are "AJ" (Alexander James) McLean, Howard Dorough (aka Howie D.), Kevin Richardson, Brian "BRok" Littrell, and Nick Carter.Take That from Manchester, Great Britain, as shown on the cover picture of their first album "Take That \& Party" (1992), are Jason Orange, Gary Barlow, Howard Donald, Mark Owen, and Robbie Williams.

Take That, the first boy band from Europe, and the Backstreet Boys from the U.S. epitomize the prototype of a 1990s boy band. These bands usually consisted of three to five members, performed catchy popular music regarding the tonal as well as the lyrical arrangements of the band's songs, and the band members usually did not play any musical instruments. When performing live on stage and also in their music videos, these bands often sang and danced along rather elaborate choreographies accompanied by frequent changes of clothing. Looks and clothing had become especially important since - to say it with reference to The Buggles' 1979 song - "Video Had Killed the Radio Star". Further, a "clean" image was very important because of the boy band's commercial orientation towards (mainly) female teenagers. Daryl Jamieson has noted that in order "to remain on good terms with the parents of their primarily young audience, [the Backstreet Boys] must refrain from showing any specific rebelling" ${ }^{4}$ which would go against parents' educational expectations. With this "clean image", i.e. no alcohol, no drugs, no affairs, no excessive behavior, ${ }^{5}$ boy band culture marked a clear opposition to the "bad boy image" of rappers or hip hoppers such as, for example, Snoop Dog or 2Pac and also to the grunge movement of the late 1980s and early 1990s represented by bands like Nirvana. 
5 Typically, each member of a boy band embodies a different personality stereotype. ${ }^{6}$ Looking at the Backstreet Boys and Take That, we can say that we usually find "the baby" or "the cute one" (Nick, Mark), who does not necessarily have to be the youngest member of the band; the prankster or funny guy (Brian, Robbie); the shy, gentleman-like one (Howie D., Jason); the "cool rebel" (AJ, Robbie) who, during his career, often likes to highlight this image by a growing number of piercings and tattoos; the dancer who is sometimes referred to as "the body" (Kevin, Howard); and in very rare cases also the singer/ songwriter (Gary), who is often the only one capable of playing a musical instrument. Furthermore, unlike most of the early European boy bands, U.S. boy bands often consisted of members coming from non-white, ethnic backgrounds, like, for example, the Latin American Howie D. from the Backstreet Boys whose parents are of Puerto-Rican and Irish descent. In the prelude to the Backstreet Boys' very first video, "We've Got It Going On" (1995), Howie D. greets his fans in Spanish and thus explicitly addresses a larger, multi-ethnic audience which includes Spanish-speaking communities in the U.S. as well as abroad. ${ }^{7}$

Since the Backstreet Boys' first single "We've Got It Goin' On" had more or less failed the U.S. market but was a top-5-hit in large parts of Western Europe (including France, Germany, Austria, Switzerland, and Holland), the Backstreet Boys' management decided to concentrate on the European music market and thus sent the boys on a promotion tour through Western Europe in the summer following the release of "We've Got It Going On". In Western Europe, the Backstreet Boys' popularity grew rapidly. The group joined the wave of success which European boy bands like Take That had already been enjoying for a couple of years, especially in Great Britain and the German-speaking countries. With the money gained from their record sales in Europe and from their very successful first tour through Europe, the Backstreet Boys, once they were back in the States, finally started touring U.S. high schools in order to establish a fan community on that side of the Atlantic. ${ }^{8}$ By that time, Take That, who had originally started their career by playing in gay bars in Britain, had almost reached the peak of their success with the release of their song "Back for Good" (1995). A couple of months later, Robbie Williams left the band that split up altogether the following year.

7 Part of the boy bands' huge success during the 1990s was based on the special type of masculinity that these bands embodied. Boy band masculinity, as I want to show, is strategically performed as an "innocent" masculinity which is especially appealing to young teenage girls (and their parents). However, boy bands could only be so successful because they delivered to much larger audiences. As will be shown, boy band culture did not only affect teenage girls but also queer audiences (e.g. gay boys, drag kings) and it made (presumably heterosexual) adolescents reflect upon their sexual desires.

\section{Jumping on Stage, or. Performing Boy Band Masculinity}

8 In prevailing discourses on boy band culture, analogies between the performance of "inauthentic music" and "inauthentic gender identity" are drawn very frequently. ${ }^{9}$ The interconnections between music, masculinity, and "(in)authenticity" become particularly apparent when boy bands are being stigmatized as not being "grown" or "real" bands. This is easy to understand if we keep in mind that the members of these bands are usually 
casted by managers in highly eclectic selection processes. These bands are actively created for commercial purposes. ${ }^{10}$ Most often, they do not compose their own songs; the band members rarely play any musical instruments; the focus seems to be more on the visual than on the musical level. Unlike "real" bands who often practice in rehearsal rooms like garages or basements for many years before they play their own songs in bars and shabby clubs, boy bands first tour high schools where they perform in front of mostly female teenagers (e.g. Backstreet Boys) or they have their first appearances in gay bars (e.g. Take That).

9 This devaluation of boy bands on the level of their music has a double effect: First of all, it leads to what Oceana555, a secret Backstreet Boys' fan, describes as follows: "The media has given the Backstreet Boys such a teenybopper image, that many people don't want to like them for fear of ridicule. (...) I kept my posters and knowledge of them a secret, except to my closest friends."11 Since it is not "cool" at all among one's peer group to listen to boy bands, Oceana555 keeps her fandom a secret. This also leads to what Gayle Wald has called a "gendered hierarchy of 'high' and 'low' popular culture that specifically devalues the music consumed by teenage girls." 12 Wald here shows that, apart from hierarchical differentiations between high and popular culture, as well as between youth and "adult" culture, we encounter a further hierarchization or aesthetic discrimination in discourses on boy band culture, which is played out to the disadvantage of young, female fans: the music they listen to is valued as "less authentic" than the music consumed by male teenagers. Gayle Wald describes this bias as one of "pop girlishness" versus "punk virility"13 which, according to her, carries underlying tones of homophobia.

10 It is not only their kitschy, catchy, popular music but also the specific kind of masculinity displayed by boy bands that makes these bands "struggl[e] to conform to different criteria of authenticity and legitimacy", ${ }^{14}$ as Matthew Stahl has put it. In addition to the boy bands'musical performances, their performance of gender is also often perceived as "inauthentic" as it is considered "not masculine enough". "The question of who and what is considered real and true", as Judith Butler reminds us in Undoing Gender, "is apparently a question of knowledge. But it is also, as Foucault makes plain, a question of power. Having or bearing 'truth' and 'reality' is an enormously powerful prerogative within the social world"15 - i.e. a heteronormatively constituted social world in which the belief in sexed and gendered essentialism is still predominant; a social world which meticulously maintains the belief in traditional gender roles and sexed and gendered binaries; a social world in which it has not yet been recognized widely that, to quote Butler's famous sentence from Gender Trouble, "[t]here is no gender identity behind the expression of gender; that identity is performatively constituted by the very 'expressions' that are said to be its results."16 It is at this specific junction of music, masculinity, "(in)authenticity", and power structures, where I see the queer potentialities inherent to boy band culture: Boy bands - whether consciously or unconsciously - engage in "deconstructive practice [s]" which undermine "the notion of polarized essences." ${ }^{17}$ Queer as "doing queer" or "queering", or "as a deconstructive strategy [that] aims to denaturalize heteronormative understandings of sex, gender, sexuality, sociality, and the relations between them", ${ }^{18}$ might not be employed as an active strategy by these bands but the bands' performances invite, if not provoke, queer readings on a textual, tonal, visual, and "bodily" level. In the following paragraphs of this article, I will demonstrate in how far boy band culture bears traces of queer interventions, even though dominant discourses of boy band culture rest on heteronormative assumptions of sex, gender, and sexuality. 
11 Boy band masculinity as a masculinity which has a "queering effect" becomes visible in the Backstreet Boys' video "Quit Playing Games (With My Heart)" (1996). ${ }^{19}$ In the video, we see the boys standing / sitting next to an outdoor basketball court. It is night. It is dark. old, dry, withered leaves are spread on the ground and the bleak aesthetics of the concrete floor and the concrete buildings surrounding the basketball court do not create a particularly romantic atmosphere. In this homosocial setting (i.e. boys and sports), Brian, who sings the first stanza, addresses his former lover named "baby" with the following words: "Even in my heart I see / you're not being true to me. / Deep within my soul I feel / nothing's like it used to be." He continues: "Sometimes I wish I could turn back time / impossible as it may seem / but I wish I could so bad, baby" in order to eventually beg his "baby" to "quit playing games with [his] heart." After that, all five Backstreet Boys start the chorus in which they repeatedly ask "baby" to "quit playing games with [their] heart[s]". Imbedded in that plea is the singer's realization or confession that he "should've known from the start" that "baby" will cheat on him although this is not made more explicit in the lyrics. The second stanza is sung by Nick, who assures the gender-unspecific "you" that everything he does "is for you" and that he lives his life in order to make the addressee come back to him. After that, Nick repeats the words which were first sung by Brian whereupon the five boys start with the second chorus. The third stanza is sung by A.J. and functions as a bridge towards the song's climax. A.J.'s words are: "Baby, baby, the love that we had was so strong. / Don't leave me hanging here forever. / Oh baby, baby, this is not right". He then concludes: "Let's stop this tonight". Accordingly, in the last two choruses, the degree of suffering after the break up increases ecstatically. The emotional intensification which culminates in the couple's break up is further emphasized by a change of place and weather: The boys are now standing on the basketball court and it is raining heavily. In close-ups and slow motion pictures we see the boys who are now wearing rain-drenched, pastel-colored shirts, which stick to the boys' wet bodies. These soaked shirts are being unbuttoned bit by bit until the song reaches its final climax.

With reference to "Quit Playing Games (With My Heart)" the queer potentialities inherent to boy band culture can be perceived on several levels. When promising their neverending love, the boys are sending ambiguous messages on a textual as well as on a tonal level. Although the song - and this is true for most pop songs - is relatively trivial when it comes to its lyrics, one of the "queering elements" is its address to a sex- and genderunspecific "you". This gendered ambiguity leaves room for interpretation so that the addressee can be imagined as belonging to one or several of innumerable sexes and genders. The Backstreet Boys' lyrical avoidance of "overt sexual reference" 20 further supports this ambiguity. On a tonal level, when suffering from their love lost, the Backstreet Boys frequently sing in high-pitched, pleading, and almost whiny voices, thus staging themselves in opposition to traditional, hegemonic masculinity.

13 Dominant ideas of masculinity usually involve well-shaped, muscular bodies. In the video, the Backstreet Boys self-consciously put their bodies on display. "Boy band bodies" of the 1990s are not the "hard bodies" of body builders or action heroes of the 1980s (e.g. Arnold Schwarzenegger, Sylvester Stallone). Nor can they be described as "hard bodies" in the sense of protecting "body armors", reminding us of those soldierly bodies analyzed by Klaus Theweleit in the late 1970s. ${ }^{21}$ Instead, they "display [...] muscle which could best be described as 'defined' and 'lean' rather than 'built'" 22 as Paul McDonald has remarked in his reading of Take That videos. McDonald's main argument is that, in contemporary (boy 
band) music videos, the male body is staged as "desirable and desiring" 23 at the same time. He argues that "[u]nlike the built body, the definition of the lean body has an apparent naturalness about it. While the lean body does not have the same overblown signifiers of phallic power as the built body, the lean body still shows the male body as strong." 24 Accordingly, the "lean body" "signifies feeling as something which is unconstructed, that is to say as something 'true'."25 In McDonald's reading, the "lean body" signifies "natural", "true", "authentic" masculinity. In contrast to McDonald's definition, I understand the "lean body", i.e. the body that desires and is desirable at the same time, as a body that stimulates much more ambiguous readings of masculinity; readings of the male body which do not necessarily rely on discourses of "naturalness" or "authenticity". On the one hand, we know that - at least since the emergence of the "metrosexual urbanite" 26 in the late 1990s - the male body (just like the female body before and ever since) has been exploited as "one of the common signifiers of contemporary consumer culture." ${ }^{27}$ On the other hand, as Ralph Poole has shown, we can no longer draw a clear line between "hard" and "soft" bodies. Instead, "the borders have dissolved." 28 There are no clear lines anymore; there are only "queer lines". And it is along these lines which emphasize ambiguity and in-betweenness that we should read "boy band masculinity".

Towards the end of "Quit Playing Games (With My Heart)" we see the Backstreet Boys performing in pouring, nightly rain. In close-ups, slow motion pictures, and fuzzy camera shots, we see water running down the boys' half-naked bodies and their faces. The emerging watery shine "highlights [the bodies'] physical shape[s]"29 and "immerses the boys in a soft, liquid environment." ${ }^{30}$ However, unlike the "hard body" or "body armor" which are characterized by their impermeability that functions as a defense and as a protection against the outside (attacks; rain) as well as against the inside (emotions; tears), the bodies displayed in "Quit Playing Games (With My Heart)" become permeable from both sides: we can barely distinguish between rain and tears; between water pouring from the outside and water pouring from the inside. In a cult centering on "hardness", one of the worst things which can happen to a man - especially in public space - is "[t]o be exposed as 'soft' at the core." ${ }^{131}$ And tears obviously are one of the most explicit markers of "softness".

Jana Katz recently argued that, in the video, the boys' display of masculinity is not necessarily endangered: due to the rain, they look as if they were crying, as if they were showing "real" emotions, but they do not really have to. The rain perfectly replaces their tears. ${ }^{32}$ While Katz engages in a reading which highlights the binary opposition between "authenticity" and "inauthenticity", I am interested in slightly different questions. The pictures make us ask: Can we spot tears? Are the boys crying? Do rain and tears intermingle? Are they blending into each other? Does the rain make the (imagined) tears invisible? And finally, does the nightly, homosocial environment of collective suffering invite for "male tears"? It is not important whether or not the emotions shown in the video are "real" or "authentic". Instead, the crucial point here is that the video opens up a space in which "male tears" become a possible alternative to hegemonic constructions and assumptions of masculinity.

While, at this point, I do not want to engage in a sexually more explicit reading, which would further highlight the importance of bodily fluids in a homosocial setting like that of "Quit Playing Games (With My Heart)", I would like to briefly draw attention to Daryl Jamieson's article "Marketing Androgyny: The Evolution of the Backstreet Boys" (2007). In this article, Jamieson examines how "the presentation and marketing of the Backstreet 
Boys, and their youngest member Nick Carter in particular, encourages queer readings" 33 of the band('s performances). In the early period of the band's existence, Jamieson argues,

Nick Carter, as the youngest, most androgynous member of the band, was the Backstreet Boy who played the most sexually ambiguous role within the band. Since he appealed to both of the main groups of fans that the Boys were courting (young girls, due to his age, and gay men, due to his androgynous body-type), Wright Stuff [i.e. one of the managers] made him the front-man of the band, emphasising his youth, innocence and his sexual ambiguity. They isolated and highlighted him in the Boys' videos, they gave him more solo lines in the singles, they even put him on the cover of a gay teen magazine. ${ }^{34}$

In "Quit Playing Games (With My Heart)", Nick's status is also rather exceptional. He is the only one of the boys who never really enters the basketball court or "playing field". He remains standing in the grandstands. Whereas the other "soaking wet Boys [are] in various states of undress", ${ }^{35}$ Nick does not expose his bare chest. He just dances and watches. ${ }^{36}$ Whereas Jamieson argues that the Backstreet Boys' success was mainly due to the marketing of Nick as a "youthful, innocent, androgynous boy who needs another person to help him 'become a man'"137 - regardless of this other person being a man or a woman -, Gayle Wald even goes one step further when speaking of the Backstreet Boys' "girlish masculinity". ${ }^{38}$ For Wald, the boys' ambiguous gender play, their "girlishness", not only allows for queer readings of their lyrics and videos but also "provoke[s] considerable anxiety (typically expressed as disdain for their music), raising questions of what the Backstreet Boys 'really' are - girls or men? black or white? gay or straight? - and what it means to be a consumer of 'girl' music." ${ }^{39}$

This brings us back to the connections between music, masculinity, and "(in)authenticity": What exactly do we gain from asking questions about "authenticity" when it comes to boy bands, music, and the performance of masculinity? Not a lot, I would like to add. Questions of "authenticity" become irrelevant if we consider that boy band masculinity, just like every other gendered performance, has to be negotiated repeatedly within a socio-cultural framework. Or, in Judith Butler's words, "gender is in no way a stable identity or locus of agency from which various acts proceede [sic]; rather, it is an identity tenuously constituted in time - an identity instituted through a stylized repetition of acts." ${ }^{\text {"0 }}$ If there is no stable, "original" gender identity to what we perceive as masculinity, and if we thus need to speak of "doing masculinity" instead of "being masculine", the question of "authenticity" is rendered superfluous. Instead, we should turn to an analysis of the power structures involved in the construction of binary oppositions such as "good/ bad" or "real/ unreal" music and masculinities. In her discussion of drag performances in Undoing Gender, Butler makes us see that "we live, more or less implicitly, with received notions of reality, implicit accounts of ontology, which determine what kinds of bodies and sexualities will be considered real and true, and which kind will not." ${ }^{41}$ She further writes that

when one performance of gender is considered real and another false, or when one presentation of gender is considered authentic, and another fake, then we can conclude that a certain ontology of gender is conditioning these judgments, an ontology (an account of what gender is) that is also put into crisis by the performance of gender in such a way that these judgments are undermined or become impossible to make. ${ }^{42}$

The example of "Quit Playing Games (With My Heart)" shows us that the ambiguities inherent to boy band masculinity bear the potential to question and "queer" musical as well as sexed and gendered ontologies. In order to further strengthen my point and to 
show that boy bands seem to encourage people to respond to them on a very affective level, I would now like to turn to several ambiguous responses to boy band culture. I will first briefly introduce two examples of "affective responses" to boy band culture by punk rock bands and high school boys to afterwards engage in a more detailed discussion of drag (king) performances which explicitly refer to boy band culture.

\section{Backstage Scenarios, or: Boy Band Re-Signified}

Anyone who attended a boy band concert or who leafed through teenage magazines in the 1990s will probably remember pictures of young girls screaming, shrieking, and crying themselves close to unconsciousness when watching their beloved boy band. Some of these girls thought of committing - or even committed - suicide when their band split up or lost one of its members. Any of these reactions can be understood as an "affective response" to boy band culture. Affect, James Thompson explains, "refers to emotional, often automatic, embodied responses that occur in relation to something else - be it object of observation, recall of a memory or practical activity." ${ }^{13}$ As will be shown, "affective responses" to boy band culture can be very diverse since boy band culture functions as a highly productive stimulus which, on an emotional level, creates as many positive (fandom, affirmation) as negative (devaluation, rejection) reactions. In the following paragraphs, I will not concentrate on teenage girls' responses to boy band culture, i.e. on "girl fandom" and thus on reactions which took place right in front of the stage, but I will primarily focus on (subcultural) artistic re-interpretations and resignifications of boy band culture, i.e. on reactions that took place offstage or "backstage".

For many female teenagers, boy bands and the masculinity which they embodied - an "innocent" and "safe" because sexually inoffensive masculinity - became an ideal space into which these young girls could project their desires, conflicts, and insecurities arising during puberty. ${ }^{44}$ This was only possible because the boy bands' "girlish masculinity" 45 presented itself as a sexually not too explicit alternative to conventional heteromasculinity. However, although boy bands as "marketable products" were primarily created to address teenage girls, it is by no means appropriate to assert that their fans were exclusively female, as Monja Messner claimed in the late 1990s. According to Messner, the only male concertgoers were fathers or older brothers who had to accompany their daughters or younger sisters. ${ }^{46}$ Obviously, this observation is very limited: affective responses like fandom did not only evolve along the lines of heterosexual desire. Jeffrey Epstein and Daryl Jamieson, ${ }^{47}$ for instance, have written of the importance of boy bands for young, gay, male fans.

But if gay sexuality merely appears as a barely noticeable subtext in a band's performances, ${ }^{48}$ these performances, as Josch Hoenes and Julia Noah Munier argue, produce heteronormative conformity rather than criticize homophobic power structures. Daryl Jamieson, in turn, highlights exactly these "gay subtexts". In his article, Jamieson shows that the Backstreet Boys' videos make the male body accessible as an object of desire for everyone regardless of the viewer's sex and gender. This means that those who look for gay subtexts will find them. Furthermore, boy band masculinity opens up the possibility for self-identified male heterosexuals to question or newly negotiate their sexuality as the following example demonstrates: In a recent interview with the British Sun, Coldplay singer Chris Martin stated that, during adolescence, his favorite bands were 
"U2 and five handsome, strapping men from Stoke and Manchester [i.e. Take That]." In the interview, Martin added: "I'm not afraid to admit it, they made me ask the question 'Am I gay?"'49 The questioning of sexuality that Chris Martin refers to points to the fact that boy bands bear the potential to destabilize heteronormative assumptions about sex, gender, sexuality, and the "stability" of these categories.

The homoerotic implications or subtexts inherent to the performance of boy band masculinity - or in short: their "homo potential"50 - can function as a danger or threat towards hegemonic, heterosexual, or heteronormative masculinities. ${ }^{51}$ It is this "homophobic fear of both boy fandom and homoerotic dynamics onstage between the boy performers", ${ }^{52}$ as well as the fear of one's own potentially homosexual desires, which frequently create a strong demand to distance oneself from boy band culture. I would now like to introduce three of the numerously existing parodies on the Backstreet Boys' song and video "I Want It That Way" (1999)..$^{53}$ These performances by punk rockers, high school boys, and drag (king) troupes illustrate very well that interpretations of boy band masculinity can go into very diverse directions.

My first example is Blink-182's music video to their song "All the Small Things" (1999)..$^{54}$ In this video, the U.S. pop punk band / punk rock band performs an ironic imitation or reinterpretation of the Backstreet Boys' video "I Want It That Way". Blink-182 borrow the Backstreet Boys' setting for their video: an airport ground with the band's private jet in the background; they borrow their clothes: white suits; they (try to) borrow their dance moves; they borrow a crowd of frantically screaming fans who are holding posters up in the air. However, Blink-182 show us a heavily exaggerated version of boy band masculinity and music: the three band members show their missing, black, and rotten teeth; they expose their bare, not very muscular chests, bellies, and bottoms; they make overly sexualized gestures like licking their lips, performing fellatio with a telescope, and snatching their crotches. One female fan has a poster which says "Travis I'm pregnant!" This exemplifies that, in contrast to the clean boy band image, these boys are no virgins or ascetics at all but do have affairs with their fans. On the other hand, a completely naked male fan has written "I want it that way, baby" on his poster by which he is not only making a clear reference to the Backstreet Boys' song, but he is also sending (homo)sexually explicit messages. And finally, there is a dog with a sign saying "Mark!!" on it. Of course, this can be read as a comic statement - yet, one which carries undertones of zoophilia and zoosexuality. In their video, Blink-182 voice their criticism against mainstream pop, e.g. on implied beauty standards. However, they do this with a homophobic and misogynist undertone since they devalue "teenybopper pop as a 'feminized' form of cultural expression from which 'real' men would naturally wish to distance themselves." ${ }^{15}$

"All the Small Things" was Blink-182's biggest commercial success and Gayle Wald has shown how, for a couple of reasons, the band moved into an "ambiguous space between parody and appropriation" ${ }^{156}$ with this song. Linda Hutcheon writes of modern parody that it is an "extended repetition with critical difference. ${ }^{157}$ Parody further "can [...] be said to require a certain institutionalized set of values [...] in order to be understood, or even to exist. The interpretative or hermeneutic situation is one based upon accepted norms, even if those norms only exist to be transgressed." 58 What is striking here is that first of all, Blink-182 obviously had to be familiar with teenybopper pop and boy bands like the Backstreet Boys in order to be able to create a parodic re-interpretation of teenybopper performances. Secondly, Blink-182's parody could only be understood by those who were 
familiar with (or even fans of) teenybopper pop and the Backstreet Boys in particular. This means that the punk rockers' audience started to include listeners of pop music. And last but not least, due to the song's success especially among female fans, what was initially planned as a mockery of boy bands changed into a completely different direction so that Blink-182 "effectively became" 59 a boy band themselves. Gayle Wald explains this shift by the fact that "the popularity of 'All the Small Things' among girls threaten[ed] Blink-182's ability to hold on to punk authenticity, a quality already significantly compromised (at least from the perspective of many a punk aficionado) by the band's forays into pop."60

Blink-182's parody of the Backstreet Boys' song and in a broader sense of boy band masculinity and boy band culture mainly operates on a visual level. I would now like to turn to a parody of "I Want It That Way" which works primarily on a textual level. My second example of artistic re-interpretations and re-significations of boy band culture is a re-writing of "I Want It That Way", which turns the song into "Which Backstreet Boy is Gay?"61 This mock song plays with rumors about the Backstreet Boys' (homo)sexuality and its "mission" therefore is to find out which one of the boys is "the gay one". Already in the song's first stanza, male homosexuality is marked as "otherness" or as deviance from the heterosexual norm with the succession of the words "but - that - gay" in "But one is thatway, one backstreet boy is gay". One of the boys is not this way, i.e. heterosexual, but he is gay. The song's choruses mainly deal with the question of finding out who exactly might be the gay band member - and here, all of the boys' names are mentioned one after the other. The remaining stanzas explicitly employ gay stereotypes. The gay band member is called "a queen" and he is said to wear "women's clothes". This not only communicates a very limited understanding of male homosexuality but further carries transphobic undertones. A connection between male homosexuality and effeminacy is further drawn in the text's association of the gay band member with croquet. He does not do "manly" sports like football or rugby, but "he's playing croquet". The imagined gay backstreet boy moreover "likes Village People", i.e. the disco / dance group of the late 1970s that attracted a wide gay male audience. The Village People were especially popular among gay fans because of their catchy songs, their lyrics that picked up the male body as one of the song's central themes (e.g. in "Macho Man"), and their colorful costumes. The group is probably best known for their song "Y.M.C.A" which, after its release, quickly became a gay anthem and made the Village People into gay icons. The lyrics of "Which Backstreet Boy is Gay?" become sexually more explicit as well as more pejorative when the song claims that "he's always saying / Ain't nothing but a butt ache, / ain't nothing but a fruitcake / I never wanna hear you say / Which one of us is gay?" The song's concluding line then reads "okay, we're all gay" which cleverly reinforces the rumors about the Backstreet Boys' (homo)sexuality.

The comic re-make of "I Want It That Way" has invited innumerable re-interpretations of the "original song" over the past decade. Numerous all-boy high school groups have videotaped their interpretations and performances of this song. Furthermore, there are many animated cartoons or power point presentations and photo shows which have been created to accompany the song's lyrics. I would argue that, in most of these cases, we are dealing with a "laughing at" rather than a "laughing with" boy band masculinity, i.e. we are dealing with examples of devaluation and rejection in order to create a personal distance from non-heteronormative masculinity. However, if we take into account that "all performances [...] [are] ambiguous and open to multiple meanings", ${ }^{62}$ we might be able to consider that even these critical, often homophobic performances, which I read as 
"affective responses" to boy band culture, require that the performers not only start to think about and deal with the issue of deviant masculinities, but that they start to empathize with these in order to embody them.

My third example of re-interpretations and re-significations of boy band masculinity as "affective responses" to boy band culture comes from the field of drag (king) performances. Del LaGrace Volcano, a well-known photo-, film-, and performance artist, who is one of the authors of The Drag King Book (1999), ${ }^{63}$ gives the following definition of a drag king: "When asked, 'What's a Drag King?' I reply: 'Anyone (regardless of gender) who consciously makes a performance out of masculinity'."64 Drag kings use strategies of exaggeration and parody to deconstruct notions of rigidly binarily sexed and gendered identities playfully. Drag kings do not merely relate to boy band culture in order to distance themselves from the masculinity performed by boy bands, but they pick up boy band masculinity, transfer it to queer, subcultural contexts and thus create queer spaces in which an acting out of desirable non-heteronormative genders, sexes, and sexualities becomes intelligible as well as pleasurably livable. In Female Masculinity (1998), Judith "Jack" Halberstam writes that drag kings can "combine [...] appropriation, critique, and alternative masculinity in [their] presentation[s]." ${ }^{15}$ For Halberstam, butches and drag kings therefore are some of the best examples of the fact that "masculinity must not and cannot and should not reduce down to the male body and its effects."

The Backdoor Boys were a transgendered drag king troupe from New York City, USA, who performed in the late 1990s. They consisted of T-Rok, A-Jack, ${ }^{67}$ Billy Starr, and Harry Ballerina. Their most famous member was T Cooper, aka T-Rok, the author of the novel Lipshitz Six, or Two Angry Blondes (2006). The Backdoor Boys also had a short appearance in Venus Boyz (2002), the first full-length documentary movie about female masculinity. The drag king troupe's name is obviouésly meant as a pun on the boy band's name: it clearly refers to "the original" and in its allusion to anal sex it once more highlights speculations about the Backstreet Boys' (homo)sexuality. The Backdoor Boys' stage performances included a whole set of re-interpretations of Backstreet Boys songs. As can be seen in the video "The REAL Backdoor Boys", ${ }^{68}$ the drag kings stage themselves as "a real" boy band: they perform in front of frantically screaming fans; stuffed animals are thrown on stage; and "the boys" give interviews to "the press", i.e. the filmmaker. However, unlike the Backstreet Boys, the Backdoor Boys unabashedly exploit the "hidden meanings" behind songs like "I Want It That Way" of which T Cooper already early on in the drag king troupe's career "decided that it ha[d] to be about anal sex." performances heavily rely on "hints" at anal and oral, non-reproductive sex. The dildos and strap-ons frequently used in these performances are "good for the girls" because they prepare them "for later in life, for their husbands and stuff", as one of the troupe's members tells us in the video. This ironic comment ridicules heteronormative assumptions about a) sex and the "natural" bodies involved in sex as well as b) about girls' growing up into predictable futures marked by heterosexual marriage and motherhood. If we remind ourselves of what Linda Hutcheon has written about parody, namely that it "require[s] a certain institutionalized set of values [...] in order to be understood", ${ }^{70}$ we might want to emphasize at this point that these performances only work in specific contexts. "Successful" re-significations of boy band masculinity are therefore highly dependent on multiple factors such as: Who are the performers? Who is in the audience? Where does the performance take place, i.e. which location? Which points of reference are shared by the performers and the audience? 

societies in which only the categories of "man" and "woman" are recognized as possible 
gender identities and whose logics merely center on heterosexual reproduction in nuclear families. On the other hand, these performances engage in the construction and production of queer communities that share queer desires; they create images of possible identities beyond those of "man" and "woman" and make these livable or at least imaginable..$^{80}$ Subcultural performances like those by the Backdoor Boys and the Sissy Boyz can thus be read as re-signifying, "queering" practices which bear the potential to question sexed and gendered binaries and to open up queer spaces in which alternative masculinities can become visible as well as livable. Hence, Halberstam writes of the Backdoor Boys performing "as" Backstreet Boys that

[t]he drag king impersonation of the faggy boy band, finally, recognizes the act as a performance of neither male heterosexuality nor gay masculinity - this is rather an intricate performance of butch masculinity, queer masculinity, that represents

itself to screaming girls as a safe alternative to hetero-masculinities. ${ }^{81}$

In the 1990s, i.e. during "the decade of boy band culture", Halberstam welcomed the "contemporary Drag King [as] [...] an unexpected late-comer to the scene of drag and gender bending" and remarked that until then "the cross-dressed woman and her particular brands of masculinity"82 had been absent from this scene. The photographs in The Drag King Book were primarily taken during the mid- to late-1990s. We can thus speak of a temporal simultaneity between the heydays of boy band culture and drag king culture as both "movements" have evolved (and also vanished for the most part) roughly around the same time.

\section{Back on Stage, or. When Boys become Men?}

What are the boy bands of the 1990s doing today? Most of them do not exist any longer. However, some of the former boy band members like Justin Timberlake $\left({ }^{*} N S Y N C\right)$ or Robbie Williams (Take That) started successful solo-careers after their bands' breakups. TheBackstreet Boys never broke up officially but only consisted of four members between 2006 and 2012: Kevin Richardson had quit the band. The Backstreet Boys are now performing withNew Kids on the Block as the new super boy band NKOTBSB, starting a longawaited world tour in April 2012. Most of the former boy bands do not want to be referred to as "boy bands" any longer. Instead, they prefer being called "male vocal groups": Have boys finally "grown up" and become men? Or, as Jana Schenk has asked, should we rather speak of "mengroups"83 when referring to the re-united, "aged" boy bands of the 1990s?

Not necessarily, as the example of Take That shows: Ten years after their breakup in 1996, Take That reunited and Gary Barlow, Jason Orange, Howard Donald, and Mark Owen released their album "Beautiful World" (2006). In the summer of 2011, Take That fans, who had been waiting for this moment for almost 15 years, were granted the pleasure of seeing their "boys" reunited in the original cast together with Robbie Williams during Take That's European stadium tour, which followed the release of their album "Progress" (2010). During that tour, Take That chose an ironic approach to their band history as well as to their age. ${ }^{84}$ Jana Schenk therefore rightly asks the question whether a contemporary boy band is one that ironically pokes fun at itself..$^{85}$ In the last part of this article, I will approach this question by taking a closer look at Take That's video to their song "Happy Now" (2011) ${ }^{86}$ In the video, the five members of Take That cast another band: Fake That. Already the first shot points to the fact that the video will engage notions of "original" 
and "imitation" / "copy" or "fake" and "reality". It shows a board which reads: "Fake That. Tribute Band Auditions. This Way."

In the first part of the video, several candidates who want to join the tribute band enter the stage and perform in front of the sleepy, slightly bored, however very critical and to some extent also rather arrogant "original" band members. Gary, Robbie, Howard, Jason, and Mark watch long-haired rockers in leathery bikers' clothes, elderly gray-haired gentlemen who are beating the song's time with tambourines, and five nonsynchronously dancing, somewhat campy and effeminate young men who want to act as Take That's doubles. The situation during the audition seems to be rather hopeless since none of the performers meets Take That's taste. Finally, out of the dark and into the spotlight, five people appear who perform one scene after the other from former Take That videos. Their repertoire includes scenes from Take That's first single "Do What You Like" (1992), as well as from their first number one hit "Pray" (1993), their most successful song "Back for Good" (1995), and from "The Flood" (2010), i.e. Take That's first single after Robbie had rejoined the band.

The doubles immediately catch Take That's attention. In terms of gender, it is especially interesting that Jason's double is "a woman": a performer of "female masculinity", a drag king one could even claim. When the five doubles first enter the stage, Gary, Robbie, Mark, and Jason react very positively. They take a closer look; they nod affirmatively; they smile happily. This changes as soon as the doubles start dancing. Their frolicsome, rompy performance of "Do What You Like" and even to a larger extent the doubles' restaging of "The Flood" and "Pray" alienate Take That so that Gary, Robbie, Mark, Howard, and Jason reject the five candidates. However, these candidates cannot be turned down easily. They re-enter the stage again and again until Take That finally approve of their version of "Back for Good". ${ }^{87}$ The second part of the video thus closes with Take That applauding and congratulating the newly chosen Fake That. In the third part of the video, we see Take That and Fake That performing together onstage in front of a large audience consisting (at least) of both, men and women. Each Take That member shares a microphone with his Fake That partner. The atmosphere appears to be lighthearted, almost high-spirited and rollicking. The boys look as if they were having fun. Take That dance with their Fake That partners and they seem to adapt to Fake That's crazy, out-ofcontrol dancing style which they had rigorously rejected before. This change establishes a space in which childlike playfulness and happiness are being acted out. The scene is further full of allusions to (sexual) stereotypes about Take That and boy bands in general: Howard's partner imitates his lisp before he caresses Howard's throat and chest; after that both men embrace each other and start dancing; Jason and his (drag king) double perform elegant, rhythmic dance moves whereupon the double plays with "her" masculine parts while focusing on "her" pelvic area; Mark and his partner are the craziest dancers and at the end they even stage a kiss.

In "Happy Now", we witness a very playful and ironic approach to boy band culture and to boy band masculinity in particular. The characters on stage do not act like grown-up, mature "men". Instead, I want to argue, they are joyfully celebrating "immaturity", or, more precisely, what Judith Jack Halberstam in relation to queer subcultures has called "a politics of refusal [...] to grow up and enter [...] heteronormative adulthoods." ${ }^{88}$ This "politics of refusal" destabilizes dominant discourses in which boy band culture and fandom are constructed and dismissed as simply temporary stages on the way to "heteronormative adulthoods" which, according to Halberstam, are marked by a 
predetermined, linear movement from birth to marriage to reproduction to death. ${ }^{89}$ Similar to Halberstam's reading of the Backstreet Boys' song "I Want It That Way" and the subsequent drag king performances by the Backdoor Boys, Take That "allow us to think of boyhood, girlhood, and even tomboyhood and riot grrrlhood not as stages to pass through but as preidentities to carry forward, inhabit, and sustain" ${ }^{10}$ long into adulthood and even into "aged boy-band-hood".

At the very end of the video, we see Take That and Fake That in front of the concert hall, which resembles an old warehouse. Take That are now wearing the leather outfits from their first video "Do What You Like" which Fake That had been wearing during their casting earlier in "Happy Now". Apparently, a change of clothes has taken place. ${ }^{91}$ The "real" Take That are leaving in expensive cars whereas Fake That are staying behind. Fake That wave and bidTake That farewell with the words: "Bye. Bye. See ya. Thanks for coming." These are words which usually would have been articulated by "the original". We could therefore say that, in "Happy Now", Take That stage border-crossings and the blurring of boundaries on several levels: Based on the deliberate confusion of "original" and "copy", the band self-consciously and self-ironically engages into a discussion of boy band culture as well as masculinity in relation to the categories of age, gender, sexuality, profession, and dominant beauty standards. After their comeback, Take That have thus been able to self-referentially stage their performances in ways that would not have been possible during the heyday of their career in the 1990s.

\section{Towards a Conclusion: Queering Boy Band Masculinity}

41 Based on different examples taken from the pop cultural fields of boy band music and performances, this article has highlighted the queer potentialities inherent to boy band culture. Stigmatized by mainstream criticism as allegedly "inauthentic" in regards to their musical as well as masculine capabilities, boy bands of the 1990s, as exemplified by the Backstreet Boys and Take That, invite queer readings of their performances. For example, the Backstreet Boys' video "Quit Playing Games (With My Heart)" presents an ambiguous gender play on a textual, tonal, and bodily level. By staging the boys in a homosocial setting at night with rain pouring down their half-naked muscular bodies, the video makes use of markers of male homosexuality. However, this opening up of possible alternatives beyond hegemonic, heterosexual masculinity often produces homophobic anxieties which frequently reveal themselves in a refusal to acknowledge boy band culture as a valuable way of cultural expression. "Affective responses" to boy band culture thus can range from affirmative, frenetic fandom to dismissive, rigorous rejection. Whereas, in their re-interpretation of the Backstreet Boys' video to "I Want It That Way", a punk band such as Blink-182 parodies boy band masculinity in an attempt to distance themselves from the deviant masculinity represented by the boy band, drag (king) troupes such as the Backdoor Boys or the Sissy Boyz also refer to boy band masculinity. In queer, subcultural contexts, they stage boy band masculinity as detached from the male body, as queer masculinity, thus supporting the intelligibility of nonheteronormative genders, sexes, and sexualities by means of re-signifying practices. Finally, in order to give a more recent example of boy band masculinity, I have analyzed Take That's video to their single "Happy Now". Starting from Jana Schenk's assumption that, today, contemporary boy bands - at least those who already existed during the 1990s - self-consciously make fun of themselves as well as of their boy band image, I have 
paid special attention to the play with and deliberate confusion of the notions of "original" and "copy" staged in "Happy Now". In the video, Take That do not only blur the lines between man and woman, between masculinity and femininity, between heterosexuality and homosexuality, but they also question dominant discourses on age(based performance), profession(alism) and beauty standards. Boy band culture and boy band masculinity in particular, we can thus conclude, do not necessarily reproduce heteronormatively structured patterns. Instead, they actively invite a queering of supposedly straight lines.

\section{BIBLIOGRAPHY}

BACKSTREET BOYS, Backstreet Boys, Jive Records, 1996, CD.

BACKSTREET BOYS, Backstreet Boys: The Greatest Hits. Chapter One [2001], Sony Music

Entertainment, 2010, DVD.

BORDO, Susan, The Male Body: A New Look at Men in Public and Private, New York, Farrar, Straus and Giroux, 1999.

BUTLER, Judith, "Performative Acts and Gender Constitution: An Essay in Phenomenology and Feminist Theory", in Theatre Journal, Vol. 40, № 4, 1988, p. 519-531.

BUTLER, Judith, Gender Trouble. Feminism and the Subversion of Identity [1990], New York, London, Routledge, 1999.

BUTLER, Judith, Bodies that Matter: On the Discursive Limits of "Sex", New York, London, Routledge, 1993.

BUTLER, Judith, Undoing Gender, New York, London, Routledge, 2004.

COOPER, T, Lipshitz Six, or Two Angry Blondes, New York, Dutton, 2006.

EPSTEIN, Jeffrey, "The Boys on the Bandwagon", in The Advocate, 09 May 2000, p. 36-44.

HALBERSTAM, Judith, Female Masculinity, Durham, Duke University Press, 1998.

HALBERSTAM, Judith, "What is a Drag King?", in VOLCANO, Del LaGrace, HALBERSTAM, Judith "Jack" (eds.), The Drag King Book, London, Serpent's Tail, 1999, p. 32-58.

HALBERSTAM, Judith, In a Queer Time and Place. Transgender Bodies, Subcultural Lives, New York, London, New York University Press, 2005.

HOENES, Josch, MUNIER, Julia Noah, "A Fabulous Country of Gender. Queer-feministische Fantasiebilder von Männlichkeit und Sexualität", in KATZ, Jana, KOCK, Martina, ORTMANN, Sandra, SCHENK, Jana, WEISS, Tomka (eds.), Sissy Boyz. Queer Performance, Bremen, thealit, 2011, p. $42-56$.

HUTCHEON, Linda, A Theory of Parody: The Teachings of Twentieth-Century Art Forms [1985], Champaign, University of Illinois Press, 2000.

"I Want It That Way", Wikipedia, the free encyclopedia, http://en.wikipedia.org/wiki/ I_Want_It_That_Way, 23 November 2012, Web. 
JAMIESON, Daryl, "Marketing Androgyny: The Evolution of the Backstreet Boys", inPopular Music, Vol. 26, № 2, 2007, p. 245-258.

KATZ, Jana, "Why does it always rain on me? Boygroupvideos und Männlichkeit", in KATZ, Jana, KOCK, Martina, ORTMANN, Sandra, SCHENK, Jana, WEISS, Tomka (eds.),Sissy Boyz. Queer Performance, Bremen, thealit, 2011, p. 112-117.

MATUSOW, Cathy, "What's Sex Got to Do with It?", in Houston Press, 20 March 2003,http:// www.houstonpress.com/2003-03-20/calendar/what-s-sex-got-to-do-with-it/, 05 April 2012, Web.

McDONALD, Paul, "Feeling and Fun. Romance, dance and the performing male body in the Take That videos", in WHITELEY, Sheila (ed.), Sexing the Groove. Popular Music and Gender, New York, London, Routledge, 1997, p. 277-294.

MESSNER, Monja, "'Sie sind sooo süüüß...' Boygroups und ihre Fans - Fans und ihre Boygroups", in SPoKK (eds.), Kursbuch Jugendkultur. Stile, Szenen und Identitäten vor der Jahrtausendwende, Mannheim, Bollmann Verlag, 1997, p. 235-242.

MOoS, Jennifer, "Boy Band Culture, Transnational Exchange, and the Performance of 'Uncool' Masculinity", in FELLNER, Astrid, HAMSCHA, Susanne, HEISSENBERGER, Klaus, MOOS, Jennifer (eds.), Is It 'Cause It's Cool? Affective Encounters With American Culture, Wien, LIT Verlag, forthcoming 2013.

POOLE, Ralph J., "Preface", in POOLE, Ralph J., SEDLMEIER, Florian, WEGENER, Susanne (eds.), Hard Bodies, Wien, LIT Verlag, 2011, p. 6-20.

SALIH, Sara, Judith Butler, London, New York, Routledge, 2002.

SCHENK, Jana, "Eine boygroup ist eine boygroup ist eine boygroup", in KATZ, Jana, KOCK, Martina, ORTMANN, Sandra, SCHENK, Jana, WEISS, Tomka (eds.), Sissy Boyz. Queer Performance, Bremen, thealit, 2011, p. 16-24.

SISSY BOYZ, website, http://www.sissyboyz.de/, 23 November, Web.

SMART, Gordon, "Chris Martin: Take That made me think I was gay", in The Sun, 25 Oct 2011, n.p, http://www.thesun.co.uk/sol/homepage/showbiz/bizarre/3891730/Chris-Martin-Take-Thatmade-me-think-I-was-gay.html, 23 November 2012, Web.

STAHL, Matthew, "Authentic Boy Bands on TV? Performers and Impresarios in The Monkees and Making the Band", in Popular Music, Vol. 21, № 3, 2002, p. 307-329.

SULLIVAN, Nikki, A Critical Introduction to Queer Theory, New York, New York University Press, 2003.

TAKE THAT, Take That \& Party, BMG Records, 1992, CD.

"The REAL Backdoor Boys", video, http://www.youtube.com/watch?v=gzgseboPCP8, 23 November 2012, Web.

THEWELEIT, Klaus, Männerphantasien. Männerkörper - Zur Psychoanalyse des Weißen Terrors, Frankfurt, Main, Verlag Roter Stern, 1978.

THILMANN, Pia, WITTE, Tania, REWALD, Ben, Drag Kings. Mit Bartkleber gegen das Patriarchat, Berlin, Querverlag, 2007.

THOMPSON, James, Performance Affects: Applied Theater and the End of Effect, Basingstoke and New York, Palgrave Macmillan, 2009.

VENUS BOYZ, dir. Gabriel Bauer, Impuls Home Entertainment, 2003 [2002], DVD. 
VOLCANO, Del LaGrace, "Foreword: A Kingdom Comes", in VOLCANO, Del LaGrace, HALBERSTAM, Judith "Jack" (eds.), The Drag King Book, London, Serpent's Tail, 1999, p. 10-28.

WALD, Gayle, "'I Want It That Way'. Teenybopper Music and the Girling of Boy Bands", in Genders, 35, 2002, n. p., http://www.genders.org/g35/g35_wald.html, 13 December 2012, Web.

"Which Backstreet Boy is Gay?", lyrics,http://www.lyricsfreak.com/w/weird+al+yankovic/ which +backstreet+boy+is+gay_20145848.html, 23 November 2012, Web

\section{NOTES}

1. For the German-speaking context magazines like BRAVO and Popcorn first come to one's mind.

2. WALD, Gayle, "I Want It That Way'. Teenybopper Music and the Girling of Boy Bands", inGenders, issue 35, 2002, n. p., http://www.genders.org/g35/g35_wald.html, 13 December 2012, Web.

3. My primary examples are The Backdoor Boys, a former drag king troupe from New York City, USA, and the Sissy Boyz from Bremen, Germany. Although the Sissy Boyz do not refer to themselves as "drag kings", but describe themselves as a "queer-feminist boy band", they use drag performances as a strategy to subvert sexed and gendered binaries (and here, masculinity in particular). Cf. their homepage http://www.sissyboyz.de/, 23 November 2012, Web.

4. JAMIESON, Daryl, "Marketing Androgyny: The Evolution of the Backstreet Boys", in Popular Music, Vol. 26, № 2, 2007, p. $248 f$.

5. On the "clean" image of boy bands see also MESSNER, Monja, "'Sie sind sooo süüß...' Boygroups und ihre Fans - Fans und ihre Boygroups", in SPoKK (ed.), Kursbuch Jugendkultur. Stile, Szenen und Identitäten vor der Jahrtausendwende, Mannheim, Bollmann Verlag, 1997, p. 240.

6. For a discussion of these stereotypes see also SCHENK, Jana, "Eine boygroup ist eine boygroup ist eine boygroup", in KATZ, Jana, KOCK, Martina, ORTMANN, Sandra, SCHENK, Jana, WEISS, Tomka (eds.), Sissy Boyz. Queer Performance, Bremen, thealit, 2011, p. $19 f$.

7. For a discussion of race, ethnicity, and the "adaptation of black performance styles" in boy band culture with an emphasis on the Backstreet Boys see WALD, Gayle, art. cit., n. p., http://www.genders.org/g35/g35_wald.html, 13 December 2012, Web.

8. When the Backstreet Boys entered the European music market in the mid-1990s, they had to compete with already established boy bands from Europe. In order to become successful they had to distinguish themselves from their European counterparts: at that time, their "Americanness" became a unique feature which was strategically enacted in order to win European audiences and thus to support the Backstreet Boys' career. This "Americanness" was primarily established through visual allusions to American culture, esp. to American sports culture, and American landscapes/ settings in the band's early videos. These markers distinguished the Backstreet Boys from European boy bands and thus made the band especially appealing to European teenagers via the band's "uniqueness", whereas, on the other hand, the very same markers functioned as identificatory icons on the U.S. market. Cf. my article on "Boy Band Culture, Transnational Exchange, and the Performance of 'Uncool' Masculinity" in the 
forthcoming volume Is It 'Cause It's Cool? Affective Encounters With American Culture, in FELLNER, Astrid, HAMSCHA, Susanne, HEISSENBERGER, Klaus, MOOS, Jennifer (eds.), Is It 'Cause It's Cool? Affective Encounters With American Culture, Wien, LIT Verlag, forthcoming 2013.

9. Cf. also Gayle Wald's article in which she argues that "the characterization of boy bands as "gay'" leads to viewing them as "musically inept as well as insufficiently masculine." WALD, Gayle, art. cit., n. p., http://www.genders.org/g35/g35_wald.html, 13 December 2012, Web.

10. Cf. e.g. Monja Messner and Jana Schenk, who both write that boy bands, due to their "createdness", cannot be seen as "authentic" or "natural" bands. Messner's statement reads: "Die Boygroups sind keine 'gewachsenen' Bands, im Gegenteil. Sie sind vielmehr das Produkt cleverer Manager, deren Konzept mit den smarten Jungs genauso einfach wie auch genial ist." MESSNER, Monja, art. cit., p. 239; or Jana Schenk on the paradox of linking the idea of a boy band to that of "realness": "Außerdem scheint es geradezu paradox, diese Bands mit dem Attribut 'echt' in Verbindung zu bringen, denn sie sind der Definition nach alles andere als 'natürlich'." SCHENK, Jana, art. cit., p. 17.

11. Quoted in WALD, Gayle, art. cit., n. p., http://www.genders.org/g35/g35_wald.html, 13 December 2012, Web, my emphases.

12. Ibid.

13. Ibid.

14. STAHL, Matthew, "Authentic Boy Bands on TV? Performers and Impresarios in The Monkees and Making the Band", in Popular Music, Vol. 21, № 3, 2002, p. 324.

15. BUTLER, Judith, Undoing Gender, New York, London, Routledge, 2004, p. 215, my emphases.

16. BUTLER, Judith, Gender Trouble. Feminism and the Subversion of Identity [1990], New York/ London, Routledge, 1999, p. 33.

17. SULLIVAN, Nikki, A Critical Introduction to Queer Theory, New York, New York University Press, 2003, p. 50.

18. Ibid., p. 81.

19. The video can be accessed here: http://www.tape.tv/musikvideos/Backstreet-Boys/ Quit-Playing-Games-With-My-Heart, 19 November 2012, Web.

20. WALD, Gayle, art. cit., n. p., http://www.genders.org/g35/g35_wald.html, 13 December 2012, Web.

21. Klaus Theweleit writes about the male "body armor" ("Körperpanzer") in the second volume of his study Männerphantasien (1977 and 1978). Männerphantasien was published in English as Male Fantasies in 1987.

22. McDONALD, Paul, "Feeling and Fun. Romance, dance and the performing male body in the Take That videos", in WHITELEY, Sheila (ed.), Sexing the Groove. Popular Music and Gender, London/ New York, Routledge, 1997, p. 286.

23. Ibid., p. 284.

24. Ibid., p. 286.

25. Ibid.

26. POOLE, Ralph J., "Preface", in POOLE, Ralph J., SEDLMEIER, Florian, WEGENER, Susanne (eds.), Hard Bodies, Wien, LIT Verlag, 2011, p. 18. 
27. MCDONALD, Paul, art. cit., p. 281.

28. POOLE, Ralph J., art. cit., p. 14.

29. MCDONALD, Paul, art. cit., p. 286.

30. Ibid.

31. BORDO, Susan, The Male Body: A New Look at Men in Public and Private, New York, Farrar, Straus and Giroux, 1999, p. 55. However, Bordo also writes that "[t]ears are permissible, even admirable, when they fill the eyes of an old warrior reminiscing about battle or a jock talking about his teammates. In such contexts, tears are like the soft penis after satisfying sex: they don't demean the man but make him lovable and human - because he has proved his strong, manly core."

32. I am paraphrasing Katz's statement here in which she writes about "real/ true feelings" ("tatsächliche Gefühle"). The German text reads as follows: "Die Jungs verlieren ihre Männlichkeit nicht, denn sie müssen nicht weinen und sehen doch so aus, als täten sie's: als zeigten sie tatsächliche Gefühle." KATZ, Jana, "Why does it always rain on me? Boygroupvideos und Männlichkeit", in KATZ, Jana, KOCK, Martina, ORTMANN, Sandra, SCHENK, Jana, WEISS, Tomka (eds.), op. cit., p. 114.

33. JAMIESON, Daryl, art. cit., p. 245, emphasis in original.

34. Ibid., p. 246.

35. Ibid., p. 250.

36. See Jamieson's article for a more detailed reading of Nick's "outsider" position during the band's early years. In relation to "Quit Playing Games (With My Heart)", Jamieson also discusses Nick as an object of desire for young gay men in greater length; Nick as an embodiment of "the fear of the locker room' [...] that keeps many gay boys from participating in organised sport"; and Madonna's "Vogue" choreography as an intertext to Nick's performance in "Quit Playing Games (With My Heart)" which, according to Jamieson, culminates in "an intense, almost orgasmic expression on [Nick's] rain-damped face". JAMIESON, Daryl, art. cit., p. 250.

37. Ibid., p. 257.

38. WALD, Gayle, art. cit., n. p., http://www.genders.org/g35/g35_wald.html, 13 December 2012, Web.

39. Ibid., n. p., http://www.genders.org/g35/g35_wald.html, 13 December 2012, Web. Wald further writes that "the question of whether male fans can be straight if they derive pleasure from a band that is so obviously 'gay' has been a recurring topic of debate on the Internet, where detractors of boy bands vehemently deem the 'Spice Boys' too 'girly' for male consumption."

40. BUTLER, Judith, "Performative Acts and Gender Constitution: An Essay in Phenomenology and Feminist Theory", in Theatre Journal, Vol. 40, № 4, 1988, p. 519, emphasis in original.

41. BUTLER, Judith, Undoing Gender, op. cit., p. 214.

42. Ibid., emphasis in original.

43. THOMPSON, James, Performance Affects: Applied Theater and the End of Effect, Basingstoke and New York, Palgrave Macmillan, 2009, p. 119.

44. Cf. Anke Westphal's article "Friedhof der Kuscheltiere: Mädchen stehen auf Boybands" (quoted in HOENES, Josch, MUNIER, Julia Noah, "A Fabulous Country of 
Gender. Queer-feministische Fantasiebilder von Männlichkeit und Sexualität", in KATZ, Jana, KOCK, Martina, ORTMANN, Sandra, SCHENK, Jana, WEISS, Tomka (eds.), op. cit., p. 50). Gayle Wald puts emphasis on another important function of teenage girl fandom when she stresses the community building aspect of girl fandom which, in her opinion, creates a "sisterly solidarity" (WALD, Gayle, art. cit., n. p.) among teenage girls.

45. Ibid., http://www.genders.org/g35/g35_wald.html, 13 December 2012, Web.

46. I am paraphrasing Monja Messner here. Her original sentences read as follows: "Die Fans der Boygroups [...] sind weiblich. Und zwar ausschließlich. Trifft man auf Konzertbesucher männlichen Geschlechts, dann handelt es sich mit Sicherheit um Väter oder ältere Brüder, die ihre Töchter oder kleineren Schwestern begleiten". MESSNER, Monja, art. cit., p. 237).

47. Cf. EPSTEIN, Jeffrey, "The Boys on the Bandwagon", in The Advocate, 09 May 2000, p. 36-44 and JAMIESON, Daryl, art. cit., p. 245-258.

48. This is a summary of Hoenes and Munier's argument which, in German, reads as follows: "Denn schwule Sexualität höchstens als kaum spürbaren Subtext in den Performances vorkommen zu lassen, produziert eine heteronormative Konformität, die keinen Einspruch in homophobe Machtverhältnisse formuliert." HOENES, Josch, MUNIER, Julia Noah, art. cit., p. 47.

49. SMART, Gordon, "Chris Martin: Take That made me think I was gay", in The Sun, 25 Oct 2011, n.p., http://www.thesun.co.uk/sol/homepage/showbiz/bizarre/3891730/ChrisMartin-Take-That-made-me-think-I-was-gay.html, 23 November 2012, Web. It should also be mentioned here that Chris Martin can make his "confession" that he was a teenage Take That fan much easier in 2011 than during his adolescence. As a well-known person in the music business, who is happily married to Gwyneth Paltrow, Martin is able to admit his appreciation of Take That, especially after their successful re-union tour "Progress" in 2011.

50. HALBERSTAM, Judith, In a Queer Time and Place. Transgender Bodies, Subcultural Lives, New York/ London, New York University Press, 2005, p. 178.

51. Cf. WALD, Gayle, art. cit., n. p., http://www.genders.org/g35/g35_wald.html, 13 December 2012, Web.

52. HALBERSTAM, Judith, In a Queer Time and Place. Transgender Bodies, Subcultural Lives, op. cit., p. 177.

53. The Wikipedia entry for "I Want It That Way" lists 28 different kinds of parodies for the song, cf.http://en.wikipedia.org/wiki/I_Want_It_That_Way, 23 November, Web. You can watch the Backstreet Boys' video here: http://www.tape.tv/musikvideos/BackstreetBoys/I-Want-It-That-Way, 23 November 2012, Web. Cf. also Gayle WALD's analysis of this video and song in the larger context of teenybopper music.

54. You can watch the video here: http://www.clipfish.de/musikvideos/video/2952387/ blink-182-all-the-small-things/, 23 November 2012, Web.

55. WALD, Gayle, art. cit., n. p., http://www.genders.org/g35/g35_wald.html, 13 December 2012, Web.

56. Ibid.

57. HUTCHEON, Linda, A Theory of Parody: The Teachings of Twentieth-Century Art Forms [1985], Champaign, University of Illinois Press, 2000, p. 7.

58. Ibid., p. 95, my emphasis. 
59. WALD, Gayle, art. cit., n. p., http://www.genders.org/g35/g35_wald.html, 13 December 2012, Web, emphasis in original.

60. Ibid.

61. For the song's lyrics check, for example, http://www.lyricsfreak.com/w/weird+al +yankovic/ which+backstreet+boy+is+gay_20145848.html, 23 November 2012, Web. All quotes from the song's lyrics are taken from this website.

62. SULLIVAN, Nikki, op. cit., p. 92.

63. Another interesting book which focuses on the drag king scenes in Germany and Switzerland is THILMANN, Pia, WITTE, Tania, REWALD, Ben, Drag Kings. Mit Bartkleber gegen das Patriarchat, Berlin, Querverlag, 2007.

64. VOLCANO, Del LaGrace, "Foreword: A Kingdom Comes", in VOLCANO, Del LaGrace, HALBERSTAM, Judith "Jack" (eds.), The Drag King Book, London, Serpent's Tail, 1999, p. 16.

65. HALBERSTAM, Judith, Female Masculinity, Durham, Duke University Press, 1998, p. 253.

66. Ibid., p. 1.

67. The similarities between the names of A.J. (BSB) and A-Jack (BDB) as well as between B-Rok (BSB) and T-Rok (BDB) are, of course, part of the drag kings' play with repetition and variation. Check the following websites for a comparison of the visual staging of the Backdoor Boys "as" Backstreet Boys: http://www.houstonpress.com/2003-03-20/calendar/ what-s-sex-got-to-do-with-it/, 23 November 2012, Web, and http:// theberry.com/2010/12/28/ridiculously-awesome-backstreet-boys-photos-28-photos/\#, 23 November 2012, Web; picture number 12 (i.e. The Backstreet Boys wearing large, oversized sports shirts) compares especially well with the photograph showing the Backdoor Boys.

68. You can watch the video here: http://www.youtube.com/watch?v=gzgseb0PCP8, 23 November 2012, Web. It is extremely interesting (and funny) that The Backdoor Boys are referred to as the REAL Backdoor Boys here. In the aftermath of this group, several other drag king troupes emerged who then also called themselves the Backdoor Boys. You can watch a video by a Toronto-based drag king group performing "Which Backstreet Boy is Gay?" here: http://www.youtube.com/watch?v=egEcEQjqDxc\&feature=related, 23 November 2012.

69. MATUSOW, Cathy, "What's Sex Got to Do with It?", in Houston Press, 20 March 2003, n. p., http://www.houstonpress.com/2003-03-20/calendar/what-s-sex-got-to-do-with-it/, 05 April 2012, Web.

70. HUTCHEON, Linda, op. cit., p. 95.

71. THILMANN, Pia, WITTE, Tania, REWALD, Ben, op. cit., p. 217.

72. Also check the troupe's website on which they describe themselves as a queerfeminist boy band, i.e. "queerfeministische boygroup": http://www.sissyboyz.de/, 23 November 2012, Web.

73. Cf. http://www.sissyboyz.de/index.html, 23 November 2012, Web.

74. Cf. http://www.sissyboyz.de/index.html, 23 November 2012, Web.

75. See e.g. the picture of the Sissy Boyz on Jack Halberstam's MySpace website, in which the drag kings 'are wearing' male torsos: http://www.myspace.com/223710371, 23 November 2012, Web.

76. SALIH, Sara, Judith Butler, London, New York, Routledge, 2002, p. 64. Butler's argument concerning "doing gender" in Gender Trouble has often been understood "as an activity 
that resembles choosing an outfit from an already-existing wardrobe of clothes" (Ibid., p. 50). However, Butler tried to refute this (mis)reading in her second major contribution to gender and queer theories, Bodies that Matter: On the Discursive Limits of "Sex", New York, London, Routledge, 1993.

77. Cf. http://www.sissyboyz.de/index.html, 23 November 2012, Web.

78. BUTLER, Judith, Undoing Gender, op. cit., p. 217f. As shown in the part "Jumping on Stage, or: Performing Boy Band Masculinity" of this article, an argument similar to Butler's argument about gender can also be made about the "realness" (or authenticity) of boy band music.

79. Ibid., p. 218.

80. This is a summary of Hoenes and Munier's argument. In the German text, this reads: "Zum einen formuliert sich in ihren Performances eine Kritik an der hegemonialen Gesellschaft, die nur die geschlechtlichen Identitäten Mann und Frau anerkennen kann, und deren Logiken, die um die heterosexuelle auf Reproduktion und Produktion ausgerichtete Kleinfamilie zentriert ist. Zum anderen beteiligen sie sich aber auch an der Konstruktion und Produktion einer queeren Begehrensgemeinschaft; an der Kreation von Bildern, die Identitäten jenseits von Mann und Frau lebbar oder zumindest vorstellbar und fantasierbar machen." HOENES, Josch, MUNIER, Julia Noah,art. cit., p. 45.

81. HALBERSTAM, Judith, In a Queer Time and Place. Transgender Bodies, Subcultural Lives, op. cit., p. 179.

82. HALBERSTAM, Judith, "What is a Drag King?", in VOLCANO, Del LaGrace, HALBERSTAM, Judith "Jack" (eds.), op. cit., p. 32.

83. SCHENK, Jana, art. cit., p. 24.

84. Cf. ibid.

85. Cf. ibid.

86. You can watch the video here: http://www.tape.tv/musikvideos/Take-That/HappyNow, 23 November 2012, Web.

87. There is a certain ambivalence to Take That's attitude towards the doubles and towards their final choice. The doubles certainly do not meet normative beauty standards. They are pale-faced; they have flabby bellies; their bodies are not in best shape. It is therefore telling that the doubles are only accepted when they conceal their bodies/ skin under long coats for the re-staging of "Back for Good". Nevertheless, they are being rewarded: they get the job and thus the opportunity to perform in front of "their" fans.

88. HALBERSTAM, Judith, In a Queer Time and Place. Transgender Bodies, Subcultural Lives, op. cit., p. 179.

89. Cf. ibid., p. 2.

90. Ibid., p. 179.

91. One could also argue that Take That are "in drag" in this scene. However, in this case "drag" would not allude to men wearing women's clothes or women wearing men's clothes (and even this is a rather limited understanding of "drag" or cross-dressing) but to Take That wearing their younger selves' clothes, i.e. a certain kind of age-crossing. 


\section{ABSTRACTS}

This article explores the queer potentialities inherent in boy band culture. Boy band culture had its heyday during the mid- and late 1990s when innumerable boy bands were casted in order to successfully conquer the music market. The boy band phenomenon might at first sight seem to have evolved around a very heteronormatively structured pattern of male performers on stage and screaming female fans in front of the stage. Drawing on the work of Judith Butler, Judith "Jack" Halberstam, and Gayle Wald, this article challenges this notion and argues that boy band culture offers a space for alternative (queer) masculinities. In reference to the Backstreet Boys and Take That as my primary examples of boy bands from the 1990s, I will first identify some characteristic features shared by (almost) all boy bands. Afterwards, my reading of the Backstreet Boys' music video "Quit Playing Games (With My Heart)" (1996) will show how these bands perform a specific "boy band masculinity" which heavily relies on markers of gay culture and homoeroticism. The third part of this article deals with affective responses to boy band culture. This part primarily focuses on subcultural re-interpretations and re-significations of boy band masculinity by drag king troupes. Drag kings as performers of "female masculinity" (cf. Halberstam) use strategies of exaggeration and parody to playfully deconstruct notions of binarily gendered identity. In a final step, I will draw attention to the bands' performance of masculinity in the new millennium: Take That's music video "Happy Now" (2011) makes us ask whether, meanwhile, boy bands have started to adopt parodic performance styles themselves in order to self-consciously distance themselves from "traditional", heteronormative masculinities on the one hand side, and, maybe even more importantly, from the boy band image itself.

Cet article examine les potentialités queer de la culture des boy bands. Celle-ci a connu son apogée du milieu à la fin des années 1990, moment où un grand nombre de boy bands furent créés lors de castings afin de conquérir le marché de la musique. De prime abord, on pourrait penser que le phénomène des boy bands a évolué autour d'un modèle structuré de façon très hétéronormative : des artistes masculins sur scène et des fans féminins hurlant devant la scène. À partir des travaux de Judith Butler, Judith "Jack" Halberstam, et Gayle Wald, cet article conteste cette idée et affirme que la culture des boy bands offre un espace pour le déploiement de masculinités (queer) alternatives. Prenant les Backstreet Boys et les Take That comme exemples de boy bands des années 1990, je propose de distinguer, dans un premier temps, quelques caractéristiques communes à (presque) tous les boy bands, pour ensuite montrer, en m'appuyant sur mon interprétation du vidéo-clip "Quit Playing Games (With My Heart)» des Backstreet Boys, comment ces groupes incarnent une «masculinité boy bands" spécifique et fortement liée aux repères de la culture gay et de l'homoérotisme. La troisième partie de cet article traite de la réception de la culture boy band et des réponses qu'elle a suscitées. Cette partie se concentre sur les réinterprétations subculturelles de la masculinité des boy bands pratiquées par les troupes de drag kings. Les drag kings, en tant qu'interprètes de la "masculinité féminine » (cf. Halberstam), déploient des stratégies d'exagération et de parodie pour déconstruire de façon ludique les notions d'identité de genre binaire. Dans un dernier temps, j'aimerais attirer l'attention sur les performances de masculinité pratiquées par ces groupes depuis le début du nouveau millénaire : le vidéo-clip «Happy Now » (2011) de Take That invite à se demander si, entre-temps, les boy bands n'ont pas commencé à pratiquer l'auto-parodie, afin de se démarquer consciemment d'un 
côté des masculinités "traditionnelles » et hétéronormatives et de l'autre, peut-être de façon encore plus importante, de l'image même des boy bands.

\section{INDEX}

Mots-clés: authenticité, hétéronormativité, parodie, masculinité, Backstreet Boys, boys band, drag king, performance, queer, Take That

Keywords: authenticity, heteronormativism, parody, masculinity, Backstreet Boys, boy bands, drag king, performance, queer, Take That

\section{AUTHOR}

\section{JENNIFER J* MOOS}

Jennifer Moos, M.A., studied English Philology, Gender Studies and Linguistics in Freiburg, Germany, and Manchester, Great Britain. She currently works in American Studies at Saarland University, Germany, where she has taught courses on gender and queer theories as well as on literary and media studies. Her research interests focus on 19th- and 20th-century U.S.-American literature, film, and music, on feminist, gender, queer, and trans* theories as well as on critical sleep studies. In her PhD project "The Pleasures of Sleeping", she examines the connections between representations of sleep and sleeplessness in U.S. American literatures and questions of nation(-building), capitalism, and the human body. She is the co-organizer of several conferences, lecture series and workshops, as well as the co-editor of two essay collections: queere ( $t$ ex (t)perimente (fwpf, 2008) and Is It 'Cause It's Cool? Affective Encounters with American Culture(LIT Verlag, forthcoming 2013). 